\title{
Impact of Sedimentation Supported by Coagulation Process on Effectiveness of Separation of the Solid Phase from Wastewater Stream
}

\author{
Piotr Maciołek ${ }^{1}$, Kazimierz Szymański ${ }^{2 *}$, Rafał Schmidt ${ }^{3}$ \\ 1 Municipal Water Supply and Sewerage Systems Co. Ltd., ul. Wojska Polskiego 14, 75-711 Koszalin, Poland \\ 2 Faculty of Civil Engineering, Environmental and Geodetic Sciences, Koszalin University of Technology, \\ ul. Śniadeckich 2, 75-453 Koszalin, Poland \\ 3 Municipal Public Utilities Company Co. Ltd., 1 Maja 1, 76-150 Darłowo, Poland \\ * Corresponding author's e-mail: kazimierzszymanski@wp.pl
}

\begin{abstract}
The objective of this work was to test the impact of coagulant and flocculant at the stage of mechanical wastewater treatment on the wastewater treatment plant operation, performed in the $\mathrm{A} 2 \mathrm{O}$ process. In this paper, the principles of correct conduct of coagulation in wastewater treatment have been discussed. It appears from the research performed that significant elimination of $\mathrm{BOD}_{5}$ such as $20 \div 30 \%$, total suspended matter up to $90 \%$, COD up to $50 \%$ and total nitrogen at 30\% level was achieved supported by the coagulation process in the pre-settling tanks. Approximately $50 \%$ of phosphorus was eliminated after the mechanical part. Additionally, a significant impact of Superfloc flocculant on the effectiveness of the solid phase separation (activated sludge) in the secondary settling tank was noted under diversified flow conditions.
\end{abstract}

Keywords: wastewater treatment, coagulation, flocculation, separation

\section{INTRODUCTION}

Municipal wastewater treatment creates serious technical and technological problems. This originates from the fact that municipal wastewater has non-uniform composition and high concentration of organic pollutants as well as contents of specific substances. The supernatant water from wastewater treatment that is returned to the wastewater treatment technological line has an impact on the wastewater treatment process. It features high contents of organic compounds and non settling suspensions containing adsorbed metals as well as gases (hydrogen sulphide and methane) and biogenic compounds. Numerous research works performed by many authors indicate that the phosphorus contents in the supernatant water coming from gravitational concentrators may amount up to $500 \mathrm{mg} / \mathrm{L}$, whereas nitrogen up to $300 \mathrm{mg} / \mathrm{L}$ [Malej \& Boguski, 2000, Malej, 2000, Piaskowski \& Ćwikałowska, 2007]. However, application of centrifugal sedimentation increases the concentrations of these pollutants up to 600 $\mathrm{mg} / \mathrm{L}$ and up to $1000 \mathrm{mg} / \mathrm{L}$, respectively [Malej, 2000, Przywara, 2006]. In order to increase the effectiveness of wastewater treatment, in physicochemical processes in coagulation-flocculation and coagulation-sedimentation-flocculation arrangements are dominant in the modern wastewater treatment systems. In the event of a necessity to particularly protect receiving waters, such as protection of seawater in the vicinity of beaches and watering places as well as protection of water intakes for alimentation of cities/towns or food industry, disinfection process is applied additionally [Duan \& Gregory, 2003, Hansen, 2002, Malej, 2008, Przywara, 2006].

The objective of this work was to test the impact of coagulant and flocculant at the stage of mechanical wastewater treatment on the wastewater treatment plant operation, performed in the $\mathrm{A} 2 \mathrm{O}$ process. 


\section{METHODOLOGY OF RESEARCH}

Wastewater is transported to "Jamno" Wastewater Treatment Plant by gravity via a $1800 \mathrm{~mm}$ sewer pipe. The wastewater treatment plant operating in the $\mathrm{A} 2 \mathrm{O}$ arrangement/system, which ensures highly efficient elimination of carbon, nitrogen and phosphorus compounds, is composed of mechanical and biological parts. The designed wastewater treatment plant throughput was defined at $40000 \mathrm{~m}^{3} / \mathrm{d}$ level, whereas the average volume of wastewater supplied to the plant in 2017 via the sewerage system, was only $24783 \mathrm{~m}^{3} / \mathrm{d}$.

The mechanical part is composed of a handoperated screen with $100 \mathrm{~mm}$ clearance, three step screens with $3 \mathrm{~mm}$ clearance and three sand traps with horizontal flow before which PIX113 coagulant is added to wastewater in the amount of $35 \div 90 \mathrm{~g}$ PIX $/ \mathrm{m}^{3}$ and two rectangular two-chamber oblong pre-settlings tanks. The coagulation process is supported, before the settling tanks, with anionic polymer added in proportion to wastewater flow rate $\left(0.02 \div 0.1 \mathrm{~g} / \mathrm{m}^{3}\right.$ PRAESTOL 2530). Such process supports the wastewater purification, particularly when high pollutant load is delivered in effluents from the sludge management area [Cherchi et al., 2009, Dziubek \& Kowal, 1988, Dincer \& Kargi, 2000, Lemmer, 2000, Malej, Boguski, 2000, Maciołek et al, 2016]. Following primary treatment, wastewater flows by gravity into two multistage A2O biological reactors operating in parallel. The dephosphatization, denitrification, nitrification and carbon biodegradation processes proceed in individual activated sludge chambers. The flow dia- gram of the biological wastewater treatment plant part is shown in Figure 1.

Beyond the pre-settling tank part of raw wastewater (approx. 20\%) flows to the pre-denitrification chamber, whereas the remaining volume flows directly into the anaerobic chamber (KB1, then KB2). The denitrification process is performed in three subsequent chambers with internal recirculation flowing from the last nitrification chamber to the first denitrification chamber. The volume of such internal recirculation depends on the concentration of nitrates $(\mathrm{V})$ in the aerobic chamber (nitrification). Before wastewater is supplied to the secondary settling tank, it is subjected to fine bubble aeration in nitrification chambers $(\mathrm{KN})$. The same coagulant as the one used in the mechanical treatment stage, i.e. iron (III) sulphate (VI) with commercial name PIX113 is added (from $15 \mathrm{~g}$ to $80 \mathrm{~g} / \mathrm{m}^{3}$ ) before the radial secondary settling tanks to the distribution chamber; it prevents the secondary liberation of phosphorus from the activated sludge bacteria cells and promotes a simultaneous phosphorus precipitation. The sludge external recirculation flows from the settling tank to the pre-denitrification chamber (KPDN) at 100-150\% Q level. The purified wastewater is channelled to the receiving water, which is the Dzierżęcinka river, supplying the Jamno coastal lake.

Raw and mechanically purified wastewater (beyond the pre-settling tanks) was taken as daily average samples in 2015 with automatic samplers in proportion to the flow rate, in weekly intervals. The following pollution indicators were determined in the taken averaged samples: COD,

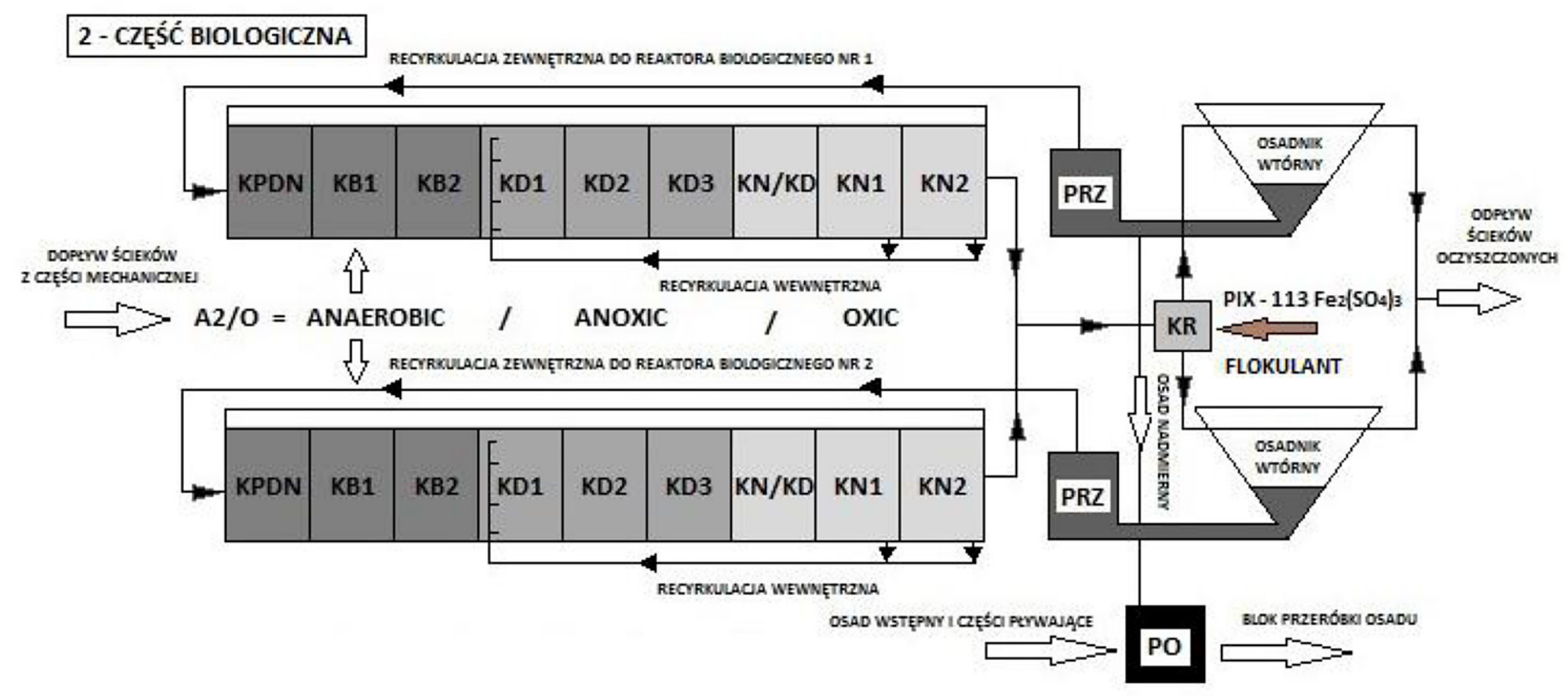

Figure 1. Flow diagram of the biological part in JAMNO Wastewater Treatment Plant 
$\mathrm{BOD}_{5}$, total suspended matter and total phosphorus. The analyses were performed in the wastewater treatment plant laboratory using recommended laboratory methods: COD Merck method 1.14541.0001, $\mathrm{BOD}_{5}-\mathrm{PN}-\mathrm{EN} 1899$, total suspended matter - PN-EN 872, total phosphorus Merck method 1.14729.0001.

Furthermore, variations of the height of the clarified zone in secondary settling tanks No 1 and No 2, monitored in March 2016, are presented in this paper. Variations of the clarified zone are illustrated in a graph based on the on-line record of Turbimax CUS71D Endress+Hauser probe, under normal wastewater flow conditions (during a single day) and during water hammering (two days). At the same time, SUPERFLOC polymer was added during the experiment into settling tank No 2 to improve the deposit sedimentation rate. Secondary settling tank No 1 operated without flocculant additive, which allowed for comparison and testing of its effectiveness in phase separation.

\section{RESEARCH RESULTS}

Supporting of wastewater treatment with coagulant and polymer in the mechanical stage is particularly significant due to high variability of raw wastewater composition, practically during the entire year. Variability of concentration of the analysed indicators in raw wastewater and after sedimentation in the pre-settling tank is illustrated in Figures 2-5. The presence of pre-settling tanks supported by chemical precipitation allows for reduction and stabilisation of pollutant loads entering the biological part. Therefore, by increased effectiveness of elimination of the solid phase from wastewater stream in the pre-settling tanks, the load of biological chambers with pollutants is reduced, resulting in practical benefits. Those benefits originate, first and foremost, from the reduction of excess sludge increase, with a simultaneous reduction of the oxygen consumption and demand. By applying such solution we strive for improvement of the economic and energetic wastewater treatment effectiveness.

The coagulation process conducted before the pre-settling tanks definitely improved the quality of mechanically purified wastewater. Nevertheless, the lack of chemical support of sedimentation process in the pre-settling tanks contributed, in connection with the periodical problem of preliminary sludge disposal (due to low temperature), to deterioration of the solid phase separation results. The height of sludge laying in pre-settling tanks at that period (without chemical support from PRAESTOL 2530 flocculant), measured with hand-operated Burkle Vampire Sampler, was approximately 1 metre below the wastewater table. Reintroduction of the chemical support from PRAESTOL 2530 caused reduction of sludge layer height in the pre-settling tanks down to approximately 3.4 metre below the wastewater table.

The absence of chemical sedimentation support in the analysed period caused a significant deterioration of the mechanical wastewater treatment results. Table 1 shows examples of the analysed parameters values achieved after the pre-settling tank without flocculant application, which are similar to those of raw wastewater.

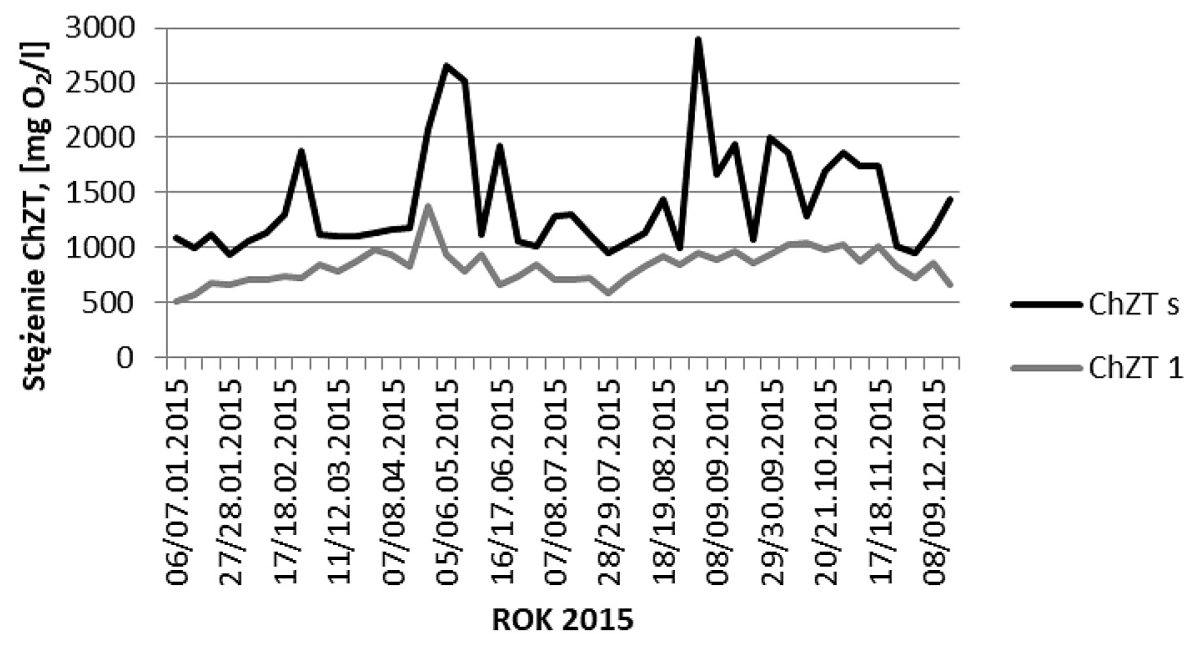

Figure 2. COD values in raw wastewater (ChZT s) and after pre-settling tank No 1 (ChZT 1) in 2015 


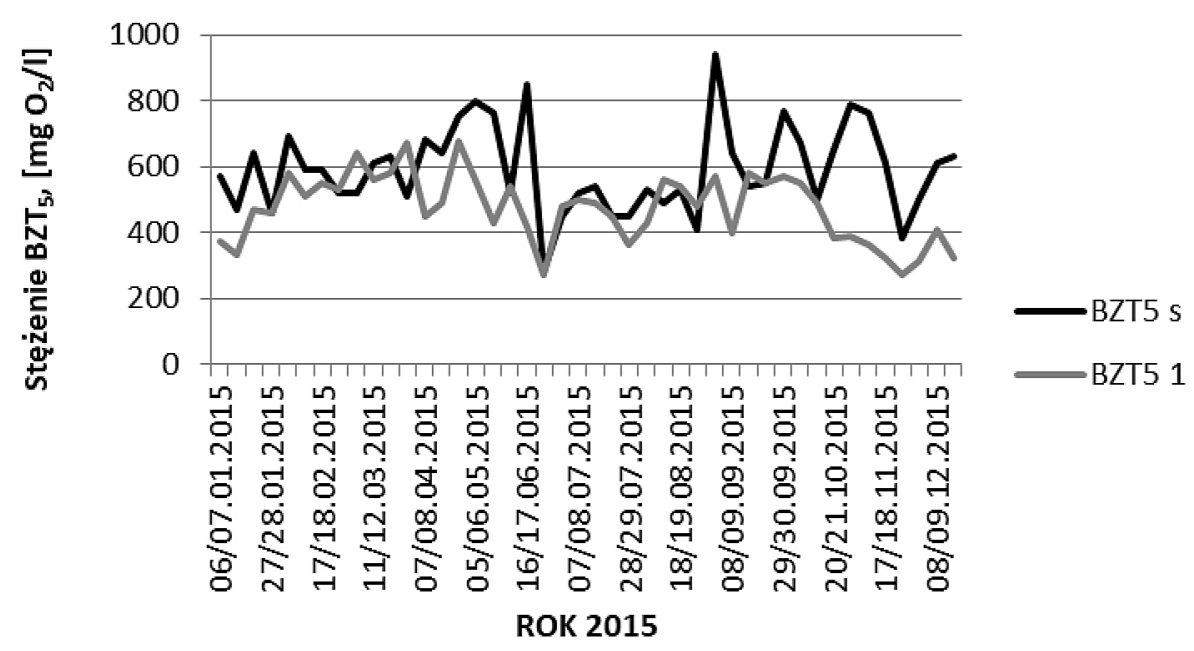

Figure 3. $\mathrm{BOD}_{5}$ values in raw wastewater $\left(\mathrm{BZT}_{5} \mathrm{~s}\right)$ and after pre-settling tank No $1\left(\mathrm{BZT}_{5} 1\right)$ in 2015

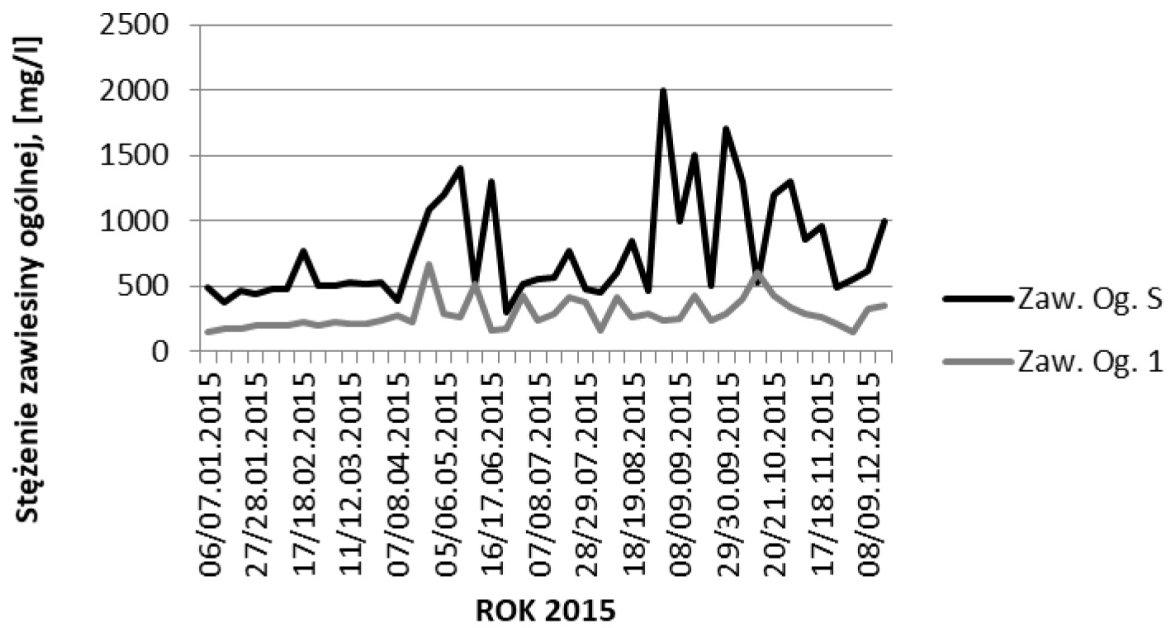

Figure 4. Total suspended matter values in raw wastewater (Zaw. Og. s) and beyond the pre-settling tank No 1 (Zaw. Og. 1) in 2015

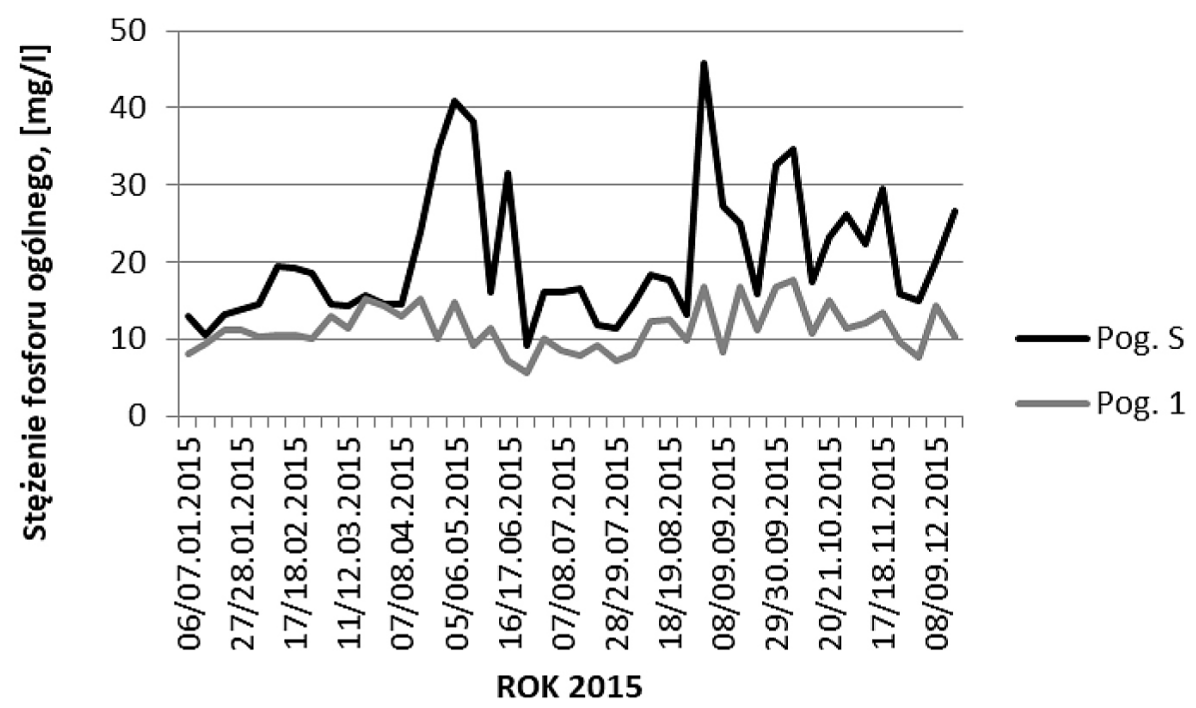

Figure 5. Total phosphorus values in raw wastewater (P og. s) and beyond the pre-settling tank No 1 (P og. 1) in 2015 
During the research period, the performance of the secondary settling tanks was also observed. Flocculant is added in Koszalin wastewater treatment plant, depending on needs, also into the secondary settling tanks, in which the activated sludge is separated from the purified wastewater through sedimentation. Under normal flow conditions, such separation proceeds without any disturbance, and the sludge sedimentation rate depends on its concentration. If the sludge concentration is high, the rate of its sedimentation considerably decreases. In Figure No 6, variations of the height of activated sludge in the secondary settling tanks under variable flow conditions, during addition of Superfloc C 18450 polymer, are illustrated. The difference of height between a well-concentrated sludge layer in the pre-settling tank No 2, supported by addition of Superfloc C 18530, and the concentrated sludge layer without the reagent was, during water hammering, maximum $50 \mathrm{~cm}$. Under normal flow conditions, this difference was $20 \mathrm{~cm}$ on average (Maciołek, 2016). The difference in sludge layer height was determined through direct on-line measurements of height of the clarified layer using Turbimax CUS71D Endress+Hauser probes, set for "distance from water to the dead zone" measurement mode. The added flocculant (quarternary polyamine) caused, under normal flow conditions (1 day), a quick change of the sludge concentration, which was confirmed by the on-line record. The height of the clarified zone during polymer addition remained similar to that under low flow conditions. During an increased inflow of wastewater, the sludge was intensely mixed and agitated, causing interference in readings. This may prove limited application of Turbimax CUS71D probes set for "distance from water to the dead zone" measurement mode under normal flow conditions.

The "Jamno" Wastewater Treatment Plant also collects wastewater from rural areas. Such wastewater features high hydrogen sulphide con- tent. The PIX - 113 preparation, which has been applied for many years, considerably eliminates hydrogen sulphide from wastewater. Furthermore, it improves the condition of the activated sludge thus improving the operation of the biological part of the plant. During a long-term operation of said wastewater treatment plant, it was noted that cessation or reduction of coagulant addition to raw wastewater led to an excessive increase of the total phosphorus concentration in the supernatant water and effluents from the sludge management returned to the main stream of raw wastewater. An additional advantage of using PIX in preliminary chemical precipitation performed at the mechanical part of the wastewater treatment plant, can be the reduction of biological reactors volume and operating costs, particularly reduction of electrical power consumption cost. This operation had an impact on reduction of the excess sludge volume, whereas the increased volume of the preliminary sludge ( $30 \div 60 \%$ reduction of the total suspended matter) promoted the process of anaerobic stabilisation of mixed sludge. It appears from laboratory tests and observation of the wastewater treatment plant operation, that pre-settling tanks make an important and essential part before the biological process of biogenic compounds elimination. They protect the biomass from elution of phosphorus eliminating bacteria and allow for intensification of the nitrogen and phosphorus elimination from wastewater. Improperly performed preliminary coagulation process may deteriorate the denitrification and nitrification effectiveness [Malej, 2000a, Malej, 2008, Szyszko, 2015]. The speed of those processes is reduced radically.

\section{CONCLUSIONS}

Total phosphorus is eliminated in „Jamno" Wastewater Treatment Plant approximately at the

Table 1. Listing of parameters of mechanically treated wastewater beyond the pre-settling tank no 1 without flocculant added

\begin{tabular}{|c|c|c|c|c|}
\hline \multirow{2}{*}{ Date } & \multicolumn{4}{|c|}{ Tested parameter } \\
\cline { 2 - 5 } & $\mathrm{COD}[\mathrm{mg} / \mathrm{l} \mathrm{O2}]$ & $\mathrm{BOD}_{5}[\mathrm{mg} / \mathrm{l} \mathrm{O} 2]$ & Tot. s.m. $[\mathrm{mg} / \mathrm{l}]$ & Tot. P [mg/l] \\
\hline $2018-02-06$ & 1900 & 560 & 1200 & 25,8 \\
\hline $2018-02-20$ & 2340 & 1380 & 1300 & 29,2 \\
\hline $2018-02-27$ & 1306 & 400 & 550 & 22,7 \\
\hline $2018-03-06$ & 1142 & - & 430 & 16,3 \\
\hline Average value & 1672 & 780 & 870 & 23,5 \\
\hline
\end{tabular}




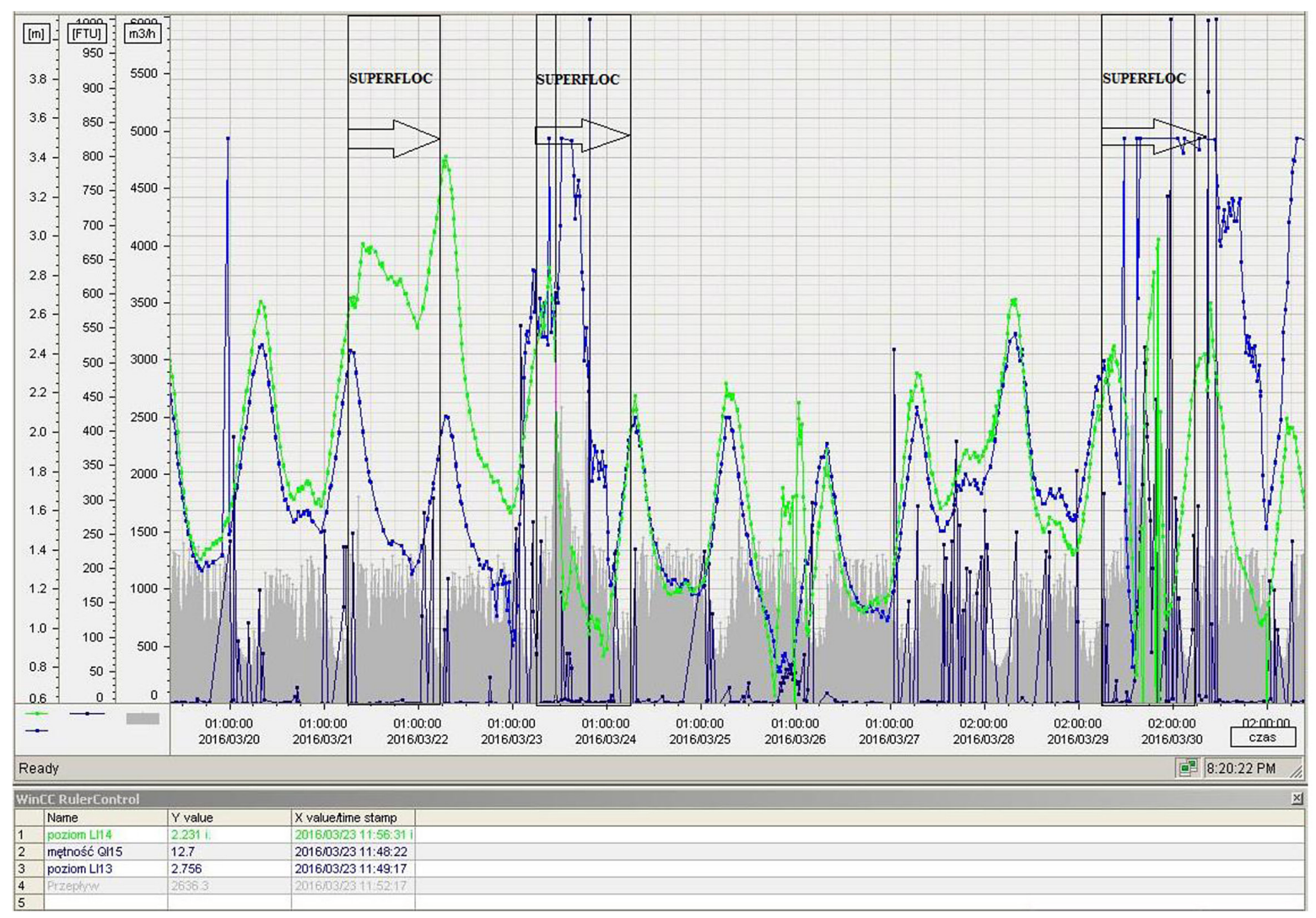

Figure 6. Variations of height of the clarified zone in the secondary sedimentation tanks No 1 (blue) and No 2 (green) with flow rate shown in the background (full graph - grey) and the measurements of turbidity (violet) under normal wastewater flow conditions $-1^{\text {th }}$ day (left area) and during water hammers $-2^{\text {nd }}$ and $3^{\text {rd }}$ day (middle and right areas). SUPERFLOC indicates the area in the course of addition of the polymer improving sludge sedimentation rate

level of $50 \%$, already after the mechanical stage of wastewater treatment supported by preliminary precipitation with iron (III) sulphate (VI) with the trade name of PIX - 113. Furthermore, the coagulant doses of $50-100 \mathrm{~g} / \mathrm{m}^{3}$ allow for $\mathrm{BOD}_{5}$ reduction by approximately $50-60 \%$, thus reducing the reactors capacity by half.

High variability of raw wastewater composition caused, as indicated by the test results of 2015 presented herein, very high variations in the biological part load during the year, when the coagulant and flocculant were not added into the pre-settling tanks,. Such irregularity may imply a non-uniform increase of the excess sludge, oxygen consumption and demand, concentration of nitrogen forms and the external and internal recirculation degree associated therewith.

Despite the application of a highly efficient biological dephosphatization method, it is still necessary to add PIX before the pre-settling tanks. The PIX-113 coagulant can be added in said wastewater treatment plant simultaneously into the biological reactors and to the distribution chamber before the secondary settling tanks; this allows for considerable improvement of the phosphorus elimination efficiency.

In the event of intensified rainfall, causing increased hydraulic load in the secondary settling tanks, the use of the polymer ultimately led to the achievement of positive effects, preventing flotation of the sludge outside overflow channels of the secondary settling tanks.

\section{REFERENCES}

1. Cherchi C., Onnis-Hayden A., El-Shawabkeh I.N., Gu A.Z. 2009. Implication of using different carbon sources for denitrification in wastewater treatments. Water Environment Research, 81(8), 788-799.

2. Dziubek, A.M., Kowal, A.L. 1988. High-pH coagulation-adsorption: a new technology for water treatment and reuse, Water Science and Technology, 21, 1183-1188.

3. Dincer K., Kargi F. 2000. Effects of operating parameters on performances of nitrification and deni- 
trification processes. Bioprocess Engineering, 23, 75-80.

4. Duan, J., Gregory, J. 2003. Coagulation by hydrolysing metal salts, Advances in Colloid and Interface Science, $100-102$, 475-502.

5. Hansen B. 2002. Chemiczne oczyszczanie ścieków - stare i nowe zastosowania. Nowe rozwiązania problemów technicznych w oczyszczalniach ścieków. Materials from a scientific and technical seminar held in Świnoujście and Copenhagen. Szczecin.

6. Klaczyński E. 2013. Oczyszczalnia ścieków chemiczne usuwanie fosforu, Wodociągi - Kanalizacja, No 2.

7. Lemmer H. 2000. Przyczyny powstawania i zwalczania osadu spęczniałego. ATV monography series. Wydawnictwo Seidel-Przywecki. Szczecin.

8. Maciołek P. 2016. Wpływ polimeru kationowego Superfloc C 18530 na właściwości sedymentacyjne osadu czynnego w zróżnicowanych warunkach przepływu. Technologia Wody, 3(47).

9. Maciołek P., Szymański K., Janowska B. 2016. Usuwanie azotu ze ścieków komunalnych z wyko- rzystaniem zewnętrznego źródła węgla organicznego. Rocznik Ochrona Środowiska, 18, 885-896.

10. Malej J., Boguski A. 2000. Zmiany ilościowe ładunku zanieczyszczeń w cieczy nadosadowej w procesie zagęszczania osadu czynnego. Rocznik Ochrony Środowiska.

11. Malej J. 2008. Wysoko sprawne oczyszczalnie ścieków a zagrożenia kąpielisk publicznych. Wodociągi - Kanalizacja, No. 11.

12. Malej J. 2000. Właściwości osadów ściekowych oraz wybrane sposoby ich unieszkodliwiania i utylizacji. Rocznik Ochrony Środowiska

13. Piaskowski K., Ćwikałowska M. 2007. Profil zmian stężenia ortofosforanów podczas oczyszczania ścieków i przeróbki osadów ściekowych. Rocznik Ochrony Środowiska.

14. Przywara L. 2006. Warunki i możliwości usuwania fosforanów i fosforu ogólnego ze ścieków przemysłowych. rozprawa doktorska, Politechnika Krakowska.

15. Szyszko M. 2015. Wpływ strącania wstępnego polimerem organicznym na szybkość denitryfikacji, www.eko-dok.pl 